\title{
Nitric Oxide Inhibition Induces Early Activation of Type I Collagen Gene in Renal Resistance Vessels and Glomeruli in Transgenic Mice
}

\author{
Role of Endothelin
}

\author{
Christos Chatziantoniou, ${ }^{*}$ Jean-Jacques Boffa, ${ }^{*}$ Raymond Ardaillou, ${ }^{*}$ and Jean-Claude Dussaule ${ }^{\ddagger}$ \\ *Institut National de la Santé et de la Recherche Médicale U.489, Hôpital Tenon, Paris 75020, France; and ${ }^{\ddagger}$ AP-HP, Faculté de Médicine \\ St. Antoine, Paris 75012, France
}

\begin{abstract}
Hypertension is often associated with the development of nephroangio- and glomerulo-sclerosis. This pathophysiological process is due to increased extracellular matrix protein, particularly type I collagen, accumulation. This study investigated whether nitric oxide (NO) synthesis is involved in the mechanism(s) regulating activation of the collagen I gene in afferent arterioles and glomeruli. Experiments were performed on transgenic mice harboring the luciferase gene under the control of the collagen $I-\alpha 2$ chain promoter [procol $\alpha 2(\mathrm{I})]$. Measurements of luciferase activity provide highly sensitive estimates of collagen I gene activation. NO synthesis was inhibited by $N^{\mathrm{G}}$-nitro-L-arginine methyl ester (L-NAME) $(20 \mathrm{mg} / \mathrm{kg}$ per day) for a period of up to $14 \mathrm{wk}$. Systolic blood pressure was increased after $6 \mathrm{wk}$ of treatment $(117 \pm 2$ versus $129 \pm 2 \mathrm{mmHg}, P<0.01)$ and reached a plateau after $10 \mathrm{wk}$ (around $160 \mathrm{mmHg}$ ). Luciferase activity was increased in freshly isolated afferent arterioles and glomeruli as early as week 4 of L-NAME treatment (150 and $200 \%$ of baseline, $P<0.01$, respectively). The activation of procol $\alpha 2$ (I) became more pronounced with time, and at 14 wk increased four- and tenfold compared with controls in afferent arterioles and glomeruli, respectively $(P<$ 0.001 ). In contrast, luciferase activity remained unchanged in aorta and heart up to $8 \mathrm{wk}$ and was increased thereafter. Increased histochemical staining for extracellular matrix deposition, and particularly of collagen I, was detected in afferent arterioles and glomeruli after $10 \mathrm{wk}$ of L-NAME treatment. This fibrogenic process was accompanied by an increased urinary excretion rate of endothelin. In separate experiments, the stimulatory effect of L-NAME on collagen I gene activation was abolished when animals were treated with bosentan, an endothelin receptor antagonist. Similarly, bosentan reduced the increased extracellular matrix deposition in afferent arterioles and glomeruli during NO inhibi-
\end{abstract}

Portions of this work were presented at the 1997 Annual Meeting of the American Society of Nephrology and have been reported in abstract form (J. Am. Soc. Nephrol. 1997. 8:A1364).

Address correspondence to Christos Chatziantoniou, INSERM U.489, Hôpital Tenon, Paris 75020, France. Phone: 331-56-01-66-58; FAX: 331-40-56-01-89.

Received for publication 25 October 1997 and accepted in revised form 17 March 1998.

J. Clin. Invest.

(C) The American Society for Clinical Investigation, Inc. 0021-9738/98/06/2780/10 \$2.00

Volume 101, Number 12, June 1998, 2780-2789

http://www.jci.org tion. Interestingly, bosentan had no effect on the L-NAMEinduced increase of systolic pressure. These data indicate that NO inhibition induces an early activation of the collagen I gene in afferent arterioles and glomeruli. This activation in the kidney precedes the increase in blood pressure and the procol $\alpha 2(\mathrm{I})$ activation in heart and aorta, suggesting a specific renal effect of NO blockade on collagen I gene expression that is independent of increased blood pressure and, at least partly, mediated through stimulation of the endothelin receptor. Use of procol $\alpha 2$ (I) transgenic mice provides a novel and efficient model to study the pathophysiological mechanism(s) regulating renal fibrosis. (J. Clin. Invest. 1998. 101:2780-2789.) Key words: hypertension • nephroangiosclerosis • renal fibrosis • extracellular matrix

\section{Introduction}

Renal vascular and glomerular sclerotic injury is one of the most frequent complications observed in human and experimental hypertension (1). The associated histological lesions include glomerular ischemia, vascular hypertrophy, and interstitial fibrosis. The renal vasculature undergoes structural changes due to extracellular matrix, particularly collagen type I, accumulation (2). This stimulation of extracellular matrix protein synthesis may occur as an adaptation to increased wall tension and/or to the action of different local vasoactive systems.

The endothelium could participate in this pathophysiological process, since it regulates the vascular tone by releasing vasoactive agents such as nitric oxide (NO) $)^{1}$ and endothelin (3, 4). Several in vivo and in vitro studies indicated that NO is an important inhibitor of vascular smooth muscle cell growth (5, 6). On the contrary, endothelin displayed mitogenic properties and induced protein synthesis in cultured vascular smooth muscle cells and mesangial cells (7-9), whereas endothelin antagonism was accompanied by reversal of vascular hypertrophy in the DOCA-salt-, angiotensin II-, or L-NAME-induced hypertension in the rat in vivo (10-12).

The objective of these studies was to evaluate whether or not and by which mechanism(s) NO is involved in the fibrogenetic process observed in the renal vasculature during hypertension. For this reason, we have applied the NO-deficiency hypertensive model to transgenic mice, a model extensively studied in the rat (13-15). We used a transgenic mouse line that expresses two reporter genes, luciferase and $\beta$-galactosidase, under the control of the promoter of collagen type I gene

1. Abbreviations used in this paper: L-NAME, $N^{\mathrm{G}}$-nitro-L-arginine methyl ester; LU, light units; NO, nitric oxide; procol $\alpha 2(\mathrm{I})$, promoter of the $\alpha 2$ chain of mouse collagen type I. 
[procol $\alpha 2(\mathrm{I})]$, because it allows changes in the expression of the collagen I gene to be detected in a highly sensitive manner (16). Afferent arterioles and glomeruli were isolated from these mice using a method based on that previously described for the rat $(17,18)$, and the procol $1 \alpha 2$ gene activation in these renal structures was compared with that found in heart and aorta. In addition, the role of endothelin in this fibrogenetic process was investigated using pharmacological blockade of endothelin receptors. Our findings suggest that NO plays a major role in the regulation of extracellular matrix synthesis in the renal vasculature. Inhibition of NO synthesis appears to induce vascular and glomerular fibrosis independently of the increase in blood pressure. This physiopathological mechanism is at least partly mediated by an endothelin-induced activation of collagen I gene expression.

\section{Methods}

Animal treatment. Male transgenic mice weighing 25-35 g (aged 2-6 mo) at the time of the experiments were maintained on a normal salt diet. Animals had free access to chow and tap water. This transgenic line, named pGB 19.5/13.5, was generated in the laboratory of B. de Crombrugghe (University of Texas, Houston, TX; reference 16). These animals harbor a construction containing the sequences -19.5 to $-13.5 \mathrm{~kb}$ and -350 to $+54 \mathrm{bp}$ of the promoter of the $\alpha 2$ chain of mouse collagen type I [procol $\alpha 2(\mathrm{I})]$ gene linked to two reporter genes, the firefly luciferase and the Escherichia coli $\beta$-galactosidase (see Fig. 1, left and middle panels). The choice of these mice was based on data showing that this construction contains a far-upstream enhancer element regulating high levels of expression of the mouse procol $\alpha 2(\mathrm{I})$ gene, and that the expression pattern of the two reporter genes in embryos closely correlates with cell and tissue distribution of collagen I (16). In preliminary experiments, we confirmed these previous findings (see Fig. 1, right panel).

To inhibit NO synthesis, mice were treated with $N^{\mathrm{G}}$-nitro-L-arginine methyl ester (L-NAME), a NO synthase inhibitor $(20 \mathrm{mg} / \mathrm{kg}$ per day). In preliminary experiments we found that this dose produced a gradual elevation of blood pressure. In a separate group of control- or L-NAME-treated mice, the mixed endothelin receptor $\left(\mathrm{ET}_{\mathrm{A}}\right.$ and $\mathrm{ET}_{\mathrm{B}}$ ) antagonist bosentan (19) was administered (20 mg/kg per day). All in vivo treatments lasted $14 \mathrm{wk}$.

Isolation of afferent arterioles and glomeruli. The technique to isolate afferent arterioles and glomeruli from the transgenic mouse kidney was based on that previously described for the rat kidney (17, 18). In mice anesthetized with pentobarbital, a midline abdominal incision was made, and the abdominal aorta was cannulated (Surflo $24 \mathrm{G}$ catheter; Terumo, Leuven, Belgium) below the renal arteries. The aorta above the kidney was ligated, the left renal vein was cut, and kidneys were perfused with ice-cold isotonic saline solution until all blood had been removed. Thereafter the kidneys were perfused with a magnetized iron oxide suspension $\left(1 \% \mathrm{Fe}_{3} \mathrm{O}_{4}\right.$ in isotonic saline). All subsequent steps of isolation were performed at $4^{\circ} \mathrm{C}$. The kidneys were removed, decapsulated, and the cortex was dissected from the medulla. Cortical tissue was homogenized with a Polytron homogenizer, and the iron oxide-loaded tissues (renal vessels and glomeruli) were removed from the crude homogenate with the aid of a magnet. Afferent arterioles were separated from larger vessels and glomeruli using repetitive passages through needles and sieves of decreasing diameter sizes (23-26 gauge and 75-25 $\mu \mathrm{m}$, respectively). The microvessels were recovered from the top of the $50-\mu \mathrm{m}$ sieve. Glomeruli were recovered from the top of the $25-\mu \mathrm{m}$ sieve. To determine if parts of afferent arterioles stayed attached to glomeruli during the separation process, glomeruli were examined under light microscopy. Only a minor part of isolated glomeruli $(<3 \%)$ had an attached portion of an afferent arteriole. Vascular preparations containing $>90 \%$ of afferent arterioles or glomeruli were retained for luciferase activity measurements. Kidneys from four mice were used to isolate afferent arterioles and glomeruli for each experiment.

Assays for the expression of reporter genes. Luciferase activity was measured in afferent arterioles, glomeruli, renal cortical slices, abdominal aorta, heart, tail, and skin using a commercial reporter gene assay kit (Boehringer Mannheim, Mannheim, Germany). Tissues were frozen immediately after removal, and $500 \mu \mathrm{l}$ of lysis buffer containing $0.1 \mathrm{M} \mathrm{KH}_{2} \mathrm{PO}_{4} / \mathrm{K}_{2} \mathrm{HPO}_{4}(\mathrm{pH}, 7.8)$ and $1 \mathrm{mM}$ DL-dithiothreitol were added in each sample. Tissues were homogenized with a Polytron homogenizer, and cells were lysed using three freezing-defreezing cycles. Thereafter, samples were centrifuged at $12,000 \mathrm{~g}$ for $15 \mathrm{~min}$, and luciferase activity was measured in $50 \mu \mathrm{l}$ of supernatant using a Lumat LB 9507 luminometer (EG \& Berthold, Evry, France). Protein content was estimated in pellets according to Bradford's method (20). Results are expressed as luciferase light units per microgram of protein $(\mathrm{LU} / \mu \mathrm{g})$. In preliminary experiments we verified that this luminometer has a linear range when assessing luciferase activity up to $10^{7} \mathrm{LU}$.

$\beta$-Galactosidase concentration, expressed as $\mathrm{pg} / \mu \mathrm{l}$, was measured on some of the above described supernatants using a commercial ELISA kit (Boehringer Mannheim).

$\beta$-Galactosidase activity was assayed on whole embryos as described previously (16). Briefly, embryos were fixed for $45 \mathrm{~min}$ in a paraformaldehyde solution, and then stained with X-gal (Boehringer Mannheim) overnight at $37^{\circ} \mathrm{C}$.

Measurement of blood pressure. Systolic blood pressure was measured by the tail-cuff method adapted to the mouse. A piezoelectric sensor (Sensonor 840-01) connected to a carrier amplifier (Kent 2) was used to detect and convert heart pulses to electric signals. The outputs of the pressure transducer were interfaced to a data acquisition system composed of a Power PC Macintosh 4400/200 computer and a MacLab/4s 16-bit analog to digital converter (ADInstruments, Castle Hill, Australia) allowing sampling at 40,000 samples/s. Pressure recording was analyzed using the Chart module of the MacLab software.

To avoid variations in blood pressure due to day cycle, all measurements were carried out between 9 and 11 A.M. Animals were accustomed for several days before measurements were made. Only animals that did not display signals of stress and that showed stable and reproducible values of blood pressure for at least three consecutive days ( $>90 \%$ of total cases) were considered for blood pressure measurements. 10 measurements from each mouse were taken at 2-min intervals. The highest and lowest values obtained from each mouse were discarded, and a mean value was determined.

Renal histology. Kidneys from at least three mice from each group were immersed in Dubosq solution. After fixation, two to three cortical slices of each kidney were embedded in paraffin after conventional processing (alcohol dehydration), and $3 \mu \mathrm{m}$-thick sections were stained with Masson trichromic solution for specific staining of extracellular matrix proteins.

Morphologic evaluation. Sections of kidneys were examined on a blinded basis for the level of glomerular sclerosis and microvascular injury using the 0-4+ injury scale, according to established methodology (13). Injury scale 0 means no damaged glomeruli, while $1,2,3$, and $4+$ correspond to $1-25,26-50,51-75$, and $76-100 \%$ of injured glomeruli, respectively. 30-40 samples (containing at least 20 glomeruli per sample) were studied in each group of animals.

Immunohistochemistry. Mice were anesthetized with pentobarbital, and kidneys were removed and immediately fixed in $3 \%$ paraformaldehyde/0.1M phosphate buffer, $\mathrm{pH} 7.4$, for $1 \mathrm{~h}$. Renal cortex was cut out to small blocks, infused with $20 \%$ sucrose in PBS, and frozen in liquid nitrogen-cooled isopentane. $4 \mu \mathrm{m}$-thick cryostat sections were preincubated in PBS containing 1\% BSA and 5\% decomplemented goat serum, immunostained with an anti-collagen type I (1 mg/ml; Rockland, Gilbertville, PA) at 1:200 dilution followed by FITC-coupled goat anti-rabbit IgG (5 mg/ml; Organon Teknika-Cappel, Durham, NC), and washed with PBS $/ 0.1 \%$ Tween. Antibodies were diluted in PBS containing $0.1 \%$ BSA and $0.5 \%$ goat serum. Sec- 
tions were mounted in an antibleach/glycerol/PBS solution (Citifluor Ltd., London, UK). Photomicrographs were obtained with a Leitz photomicroscope equipped with epifluorescence illumination using Kodak Ectachrome films (Eastman Kodak Co., Rochester, NY).

Measurement of endothelin. Urine samples of mice from the control and the 10th wk L-NAME groups were collected from the bladder of animals. Immunoreactive endothelin- 1 was measured by RIA using a Peninsula (Merseyside, UK) commercial kit as described previously (21). Each group included eight mice. Urine endothelin concentration was normalized to urine creatinine concentration, and values were expressed as $\mathrm{pg}$ of endothelin per $\mu \mathrm{mol}$ of creatinine.

Acute administration of endothelin. In a separate group of animals $(n=16)$, endothelin was injected intraperitoneally $(2 \mathrm{nmol} / \mathrm{kg})$, and renal cortical slices were isolated 4 and $20 \mathrm{~h}$ after injections. In these renal tissues luciferase activity was measured as described above.

Proteinuria. Urines of 12 mice from each group were collected from the bladder of anesthetized animals just before starting the icecold saline perfusion. Samples were centrifuged at 1,500 $\mathrm{g}$ for $5 \mathrm{~min}$, and proteins were measured by colorimetry using a specific commercial kit for proteinuria (Red of pyrogallol; Merck, Darmstadt, Germany). Urine protein concentration was normalized using urine creatinine concentration as reference, and values were expressed as milligram of protein per micromol of creatinine.

Statistical methods. Statistical analyses were performed using ANOVA followed by Protected Least Significance Difference Fisher's test of the Statview software package. Results with $P<0.05$ were considered statistically significant. All values are means \pm SEM.

\section{Results}

Validation of the model. A primary goal was to investigate whether or not NO is involved in the mechanisms of renal vascular fibrosis observed during the development of hypertension. To this end, an animal model was needed where changes in the activation of extracellular matrix formation could be detected in a sensitive and quantitative way. The procol $\alpha 2(\mathrm{I})$ transgenic mouse offers the advantage of high sensitivity of luciferase activity measurements. This advantage, combined with the fact that collagen I is scarcely present in the renal vasculature under normal conditions, made the idea to use the procol $\alpha 2(\mathrm{I})$ transgenic line to study renal fibrosis very attractive. However, our preliminary experiments (Fig. 1, right panel) and the previous studies concerning this transgenic line were carried out on embryos or new born animals (16), and several controls were necessary to validate this model in adult animals.

First, we checked whether the luciferase activity in different tissues correlates well with the collagen I distribution in adult animals. Fig. $2 \mathrm{~A}$ shows the values of luciferase activity in several tissues obtained from 2- to 6-mo-old mice. It is clear that tail and skin displayed high levels of luciferase activity (around 22,000 and 8,000 LU/ $\mu \mathrm{g}$, respectively), aorta showed moderate values (around 1,700 LU/ $\mathrm{gg}$ ), heart, renal cortex, and afferent arterioles had lower values (150,160, and 200
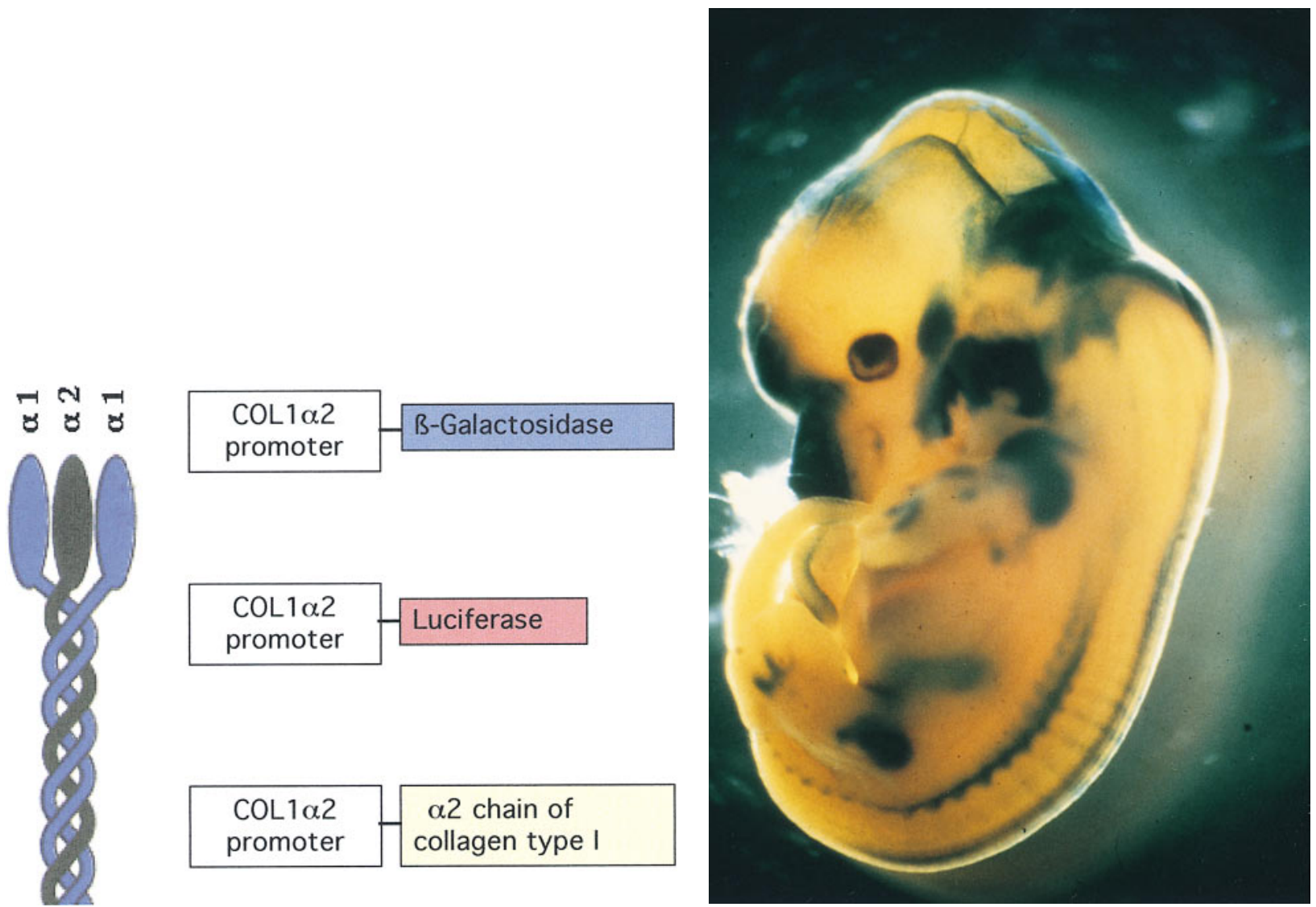

Figure 1. Representation of the transgenic mouse line procol $\alpha 2(\mathrm{I})$. Mature collagen I is a triple helix molecule containing two $\alpha 1$ and one $\alpha 2$ helices (left). Promoter construction of the two reporter genes (middle). X-gal staining of a 14-d embryo (right). Note the intense blue staining of the tissues rich in collagen. 
Table I. Luciferase Levels in Tissues of 2, 3, and 6-mo-old Transgenic Mice

\begin{tabular}{lcccc}
\hline Age & 2 & 3 & 6 & $n$ \\
\hline Tissue & & & & \\
Tail & $22108 \pm 2159$ & $21198 \pm 1376$ & $22147 \pm 1079$ & 24 \\
Skin & $8132 \pm 783$ & $8256 \pm 927$ & $7654 \pm 912$ & 24 \\
Aorta & $1492 \pm 248$ & $1949 \pm 201$ & $1701 \pm 189$ & 24 \\
Heart & $134 \pm 22$ & $151 \pm 19$ & $126 \pm 13$ & 24 \\
Renal & & & & \\
$\quad$ cortex & $161 \pm 11$ & $164 \pm 15$ & $193 \pm 21$ & 24 \\
Affer. & & & & \\
$\quad$ arterioles & $201 \pm 10$ & $235 \pm 35$ & $205 \pm 22$ & 6 \\
Glomeruli & $24 \pm 3$ & $21 \pm 2$ & $20 \pm 2$ & 6 \\
& & & & \\
\hline
\end{tabular}

Luciferase values are expressed as light units per microgram of protein; $n=$ number of mice for tail, skin, aorta, heart, and renal cortex, and $n=$ preparations (four mice per preparation) for afferent arterioles and glomeruli.
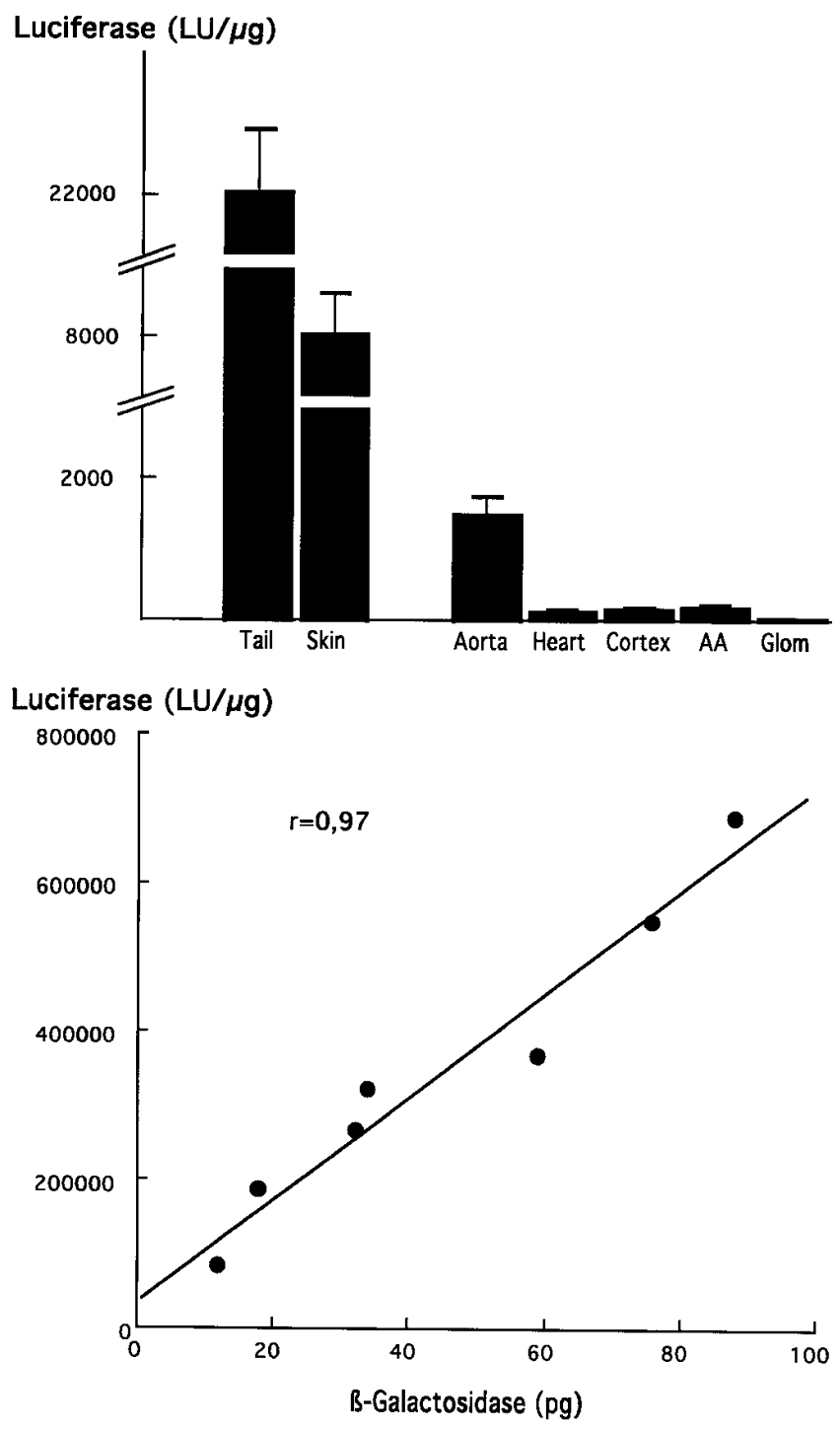

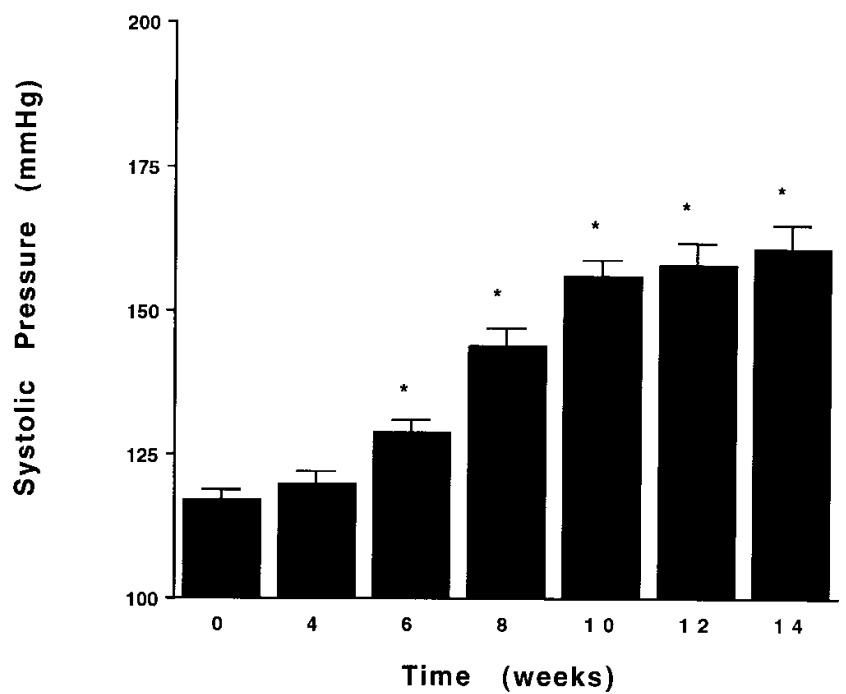

Figure 3. Systolic blood pressure measured in transgenic mice treated with L-NAME for up to $14 \mathrm{wk}$. Values are means \pm SEM of 15 mice per group. $* P<0.05$ versus control.

$\mathrm{LU} / \mu \mathrm{g}$, respectively), and glomeruli had very little luciferase activity $(20 \mathrm{LU} / \mu \mathrm{g})$. These values agree with those reported previously for new born mice and with the well-known distribution of collagen $\mathrm{I}$ in these tissues $(16,22,23)$. In addition, there was a close correlation $(r=0.97)$ between measurements of luciferase activity (LU) and the amount of $\beta$-galactosidase (ng) found in the same tissues (Fig. 2 B). To determine whether collagen I gene expression varied with age, we measured luciferase activity in tail, skin, heart, aorta, renal cortex, afferent arterioles, and glomeruli in animals aged from 2-6 mo (period of time equal to the duration of the hypertensive treatment). Table I summarizes the values of luciferase activity detected in the tissues of interest with age. No difference was observed in any of the tissues between 2 and 6 mo (Table I).

Effects of L-NAME treatment. L-NAME, a potent inhibitor of NO-synthase, was given chronically to induce hypertension. After 6 wk of L-NAME treatment, systolic pressure was significantly higher $(129 \pm 2$ versus $116 \pm 2 \mathrm{mmHg}, P<0.01$, for 6 wk and control, respectively; Fig. 3). Systolic pressure continued to rise with increasing length of L-NAME treatment and reached a plateau around $10-12$ wk $(156 \pm 4$ versus $158 \pm 3$ $\mathrm{mmHg}$, for 10 and $12 \mathrm{wk}$, respectively; Fig. 3). Staining for extracellular matrix after $6 \mathrm{wk}$ of L-NAME treatment (Fig. $4 A$ ) was similar to untreated controls (data not shown). On the contrary, increased levels of extracellular matrix formation were slightly detected after $8 \mathrm{wk}$ and became more apparent after $10 \mathrm{wk}$ in glomeruli and small vessels indicating induction of renal vascular fibrosis (Fig. $4 \mathrm{~B}$ ). Semiquantitative evaluation indicated greater glomerular injury in L-NAME-treated versus control mice (Fig. 5). Glomeruli with injury scores from

Figure 2. Tissue distribution of luciferase activity in adult mice (top). Values are means \pm SEM of eight experiments. Correlation between luciferase activity and $\beta$-galactosidase concentration in tissues of 3-mo-old mice (bottom). 

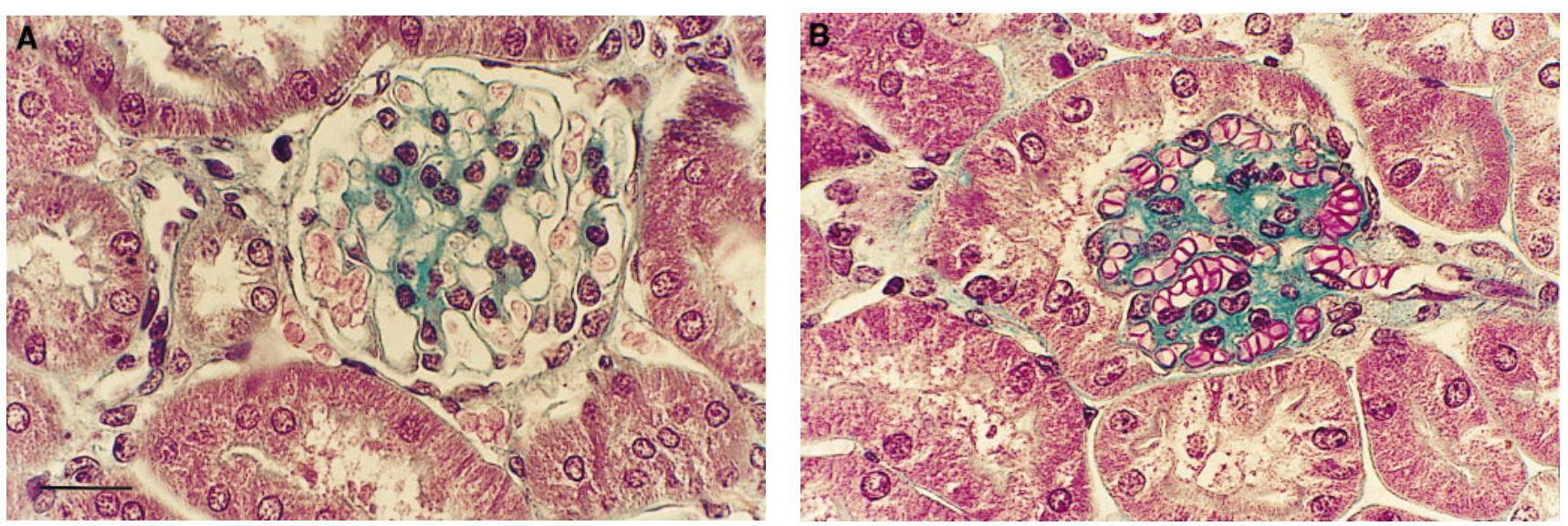

Figure 4. Representative example of extracellular matrix staining by Masson trichromic solution in a mouse treated with L-NAME for $6(A)$ and $10 \mathrm{wk}(B)$. Note the normal aspect of glomerulus at $6 \mathrm{wk}$, and the intense green staining (indicating extracellular matrix) and the flocculus retraction of glomerulus at $10 \mathrm{wk}$. Bar, $10 \mu \mathrm{m}$.

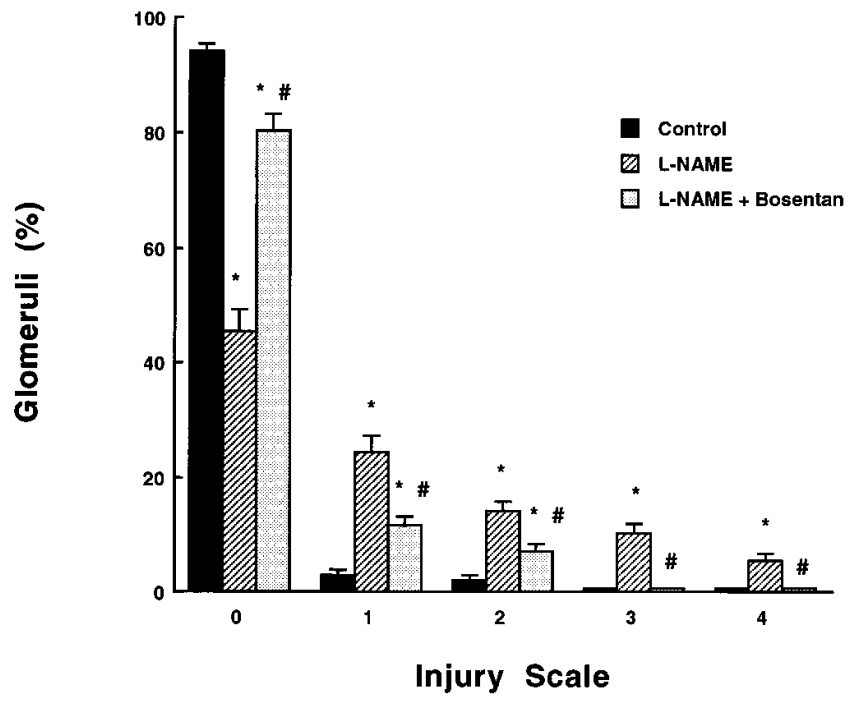

2 to $4+$ were negligible in controls, whereas they represented one third of the total glomerular population in animals treated with L-NAME for $14 \mathrm{wk}$. At least a part of the glomerular fibrosis was due to increased presence of collagene I, since immunohistochemistry of cryostat sections indicated increased collagen I positive staining in glomeruli of mice treated for $10 \mathrm{wk}$ with L-NAME (Fig. 6). Proteinuria remained unchanged compared with control values throughout the L-NAME treatment $(2.47 \pm 0.41$ versus $2.71 \pm 0.64$ and $2.75 \pm 0.77 \mathrm{mg} / \mu \mathrm{mol}$, for control, 8 and 14 wk of L-NAME treatment, respectively). Data obtained after X-gal staining were inconclusive, because renal

Figure 5. Degree of injury in glomeruli isolated from transgenic controls and mice treated with L-NAME or L-NAME + bosentan for 14 wk. $* P<0.05$ versus control; $\# P<0.05$ L-NAME versus L-NAME + bosentan-treated group.
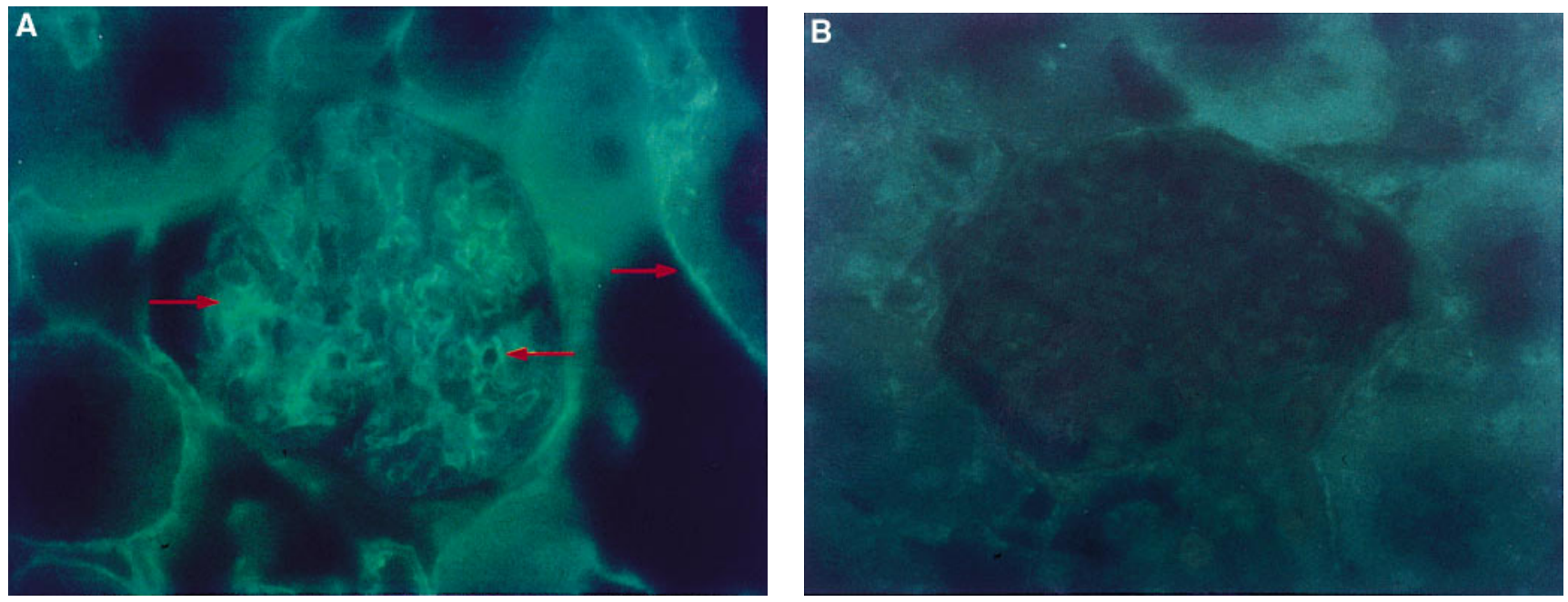

Figure 6. Representative example of immunostaining with collagen I antibody in mouse treated with L-NAME for 10 wk $(A)$ versus vehicletreated animal $(B)$. Note the intense mesangial (left-pointing arrow), peri-capillary (middle arrow) and interstitial (right arrow) staining. 

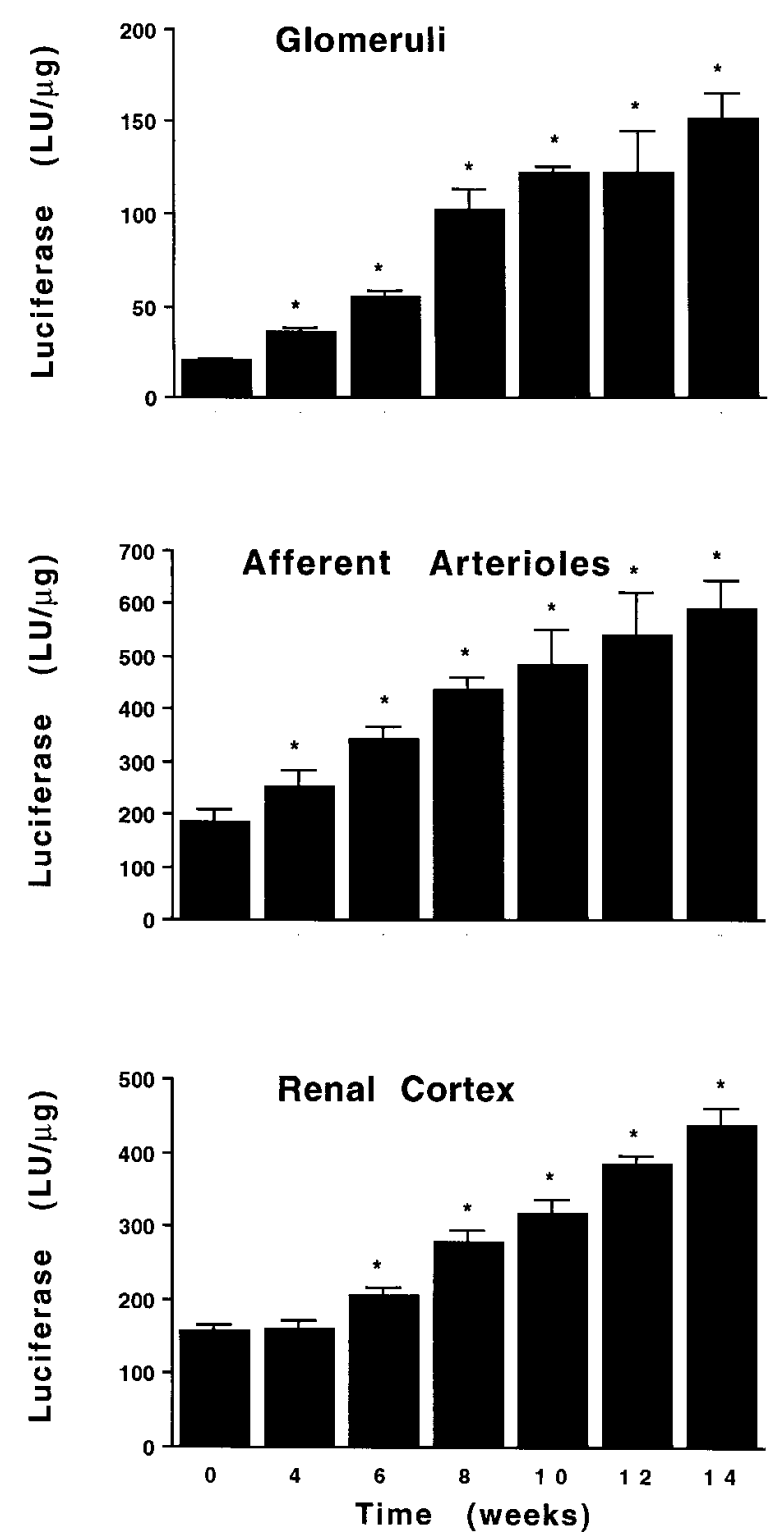

Figure 7. Luciferase activity from glomeruli (top), afferent arterioles (middle), and renal cortical slices (bottom) isolated from transgenic mice treated with L-NAME for different periods of time. Values are means \pm SEM; $n=3$ (four mice per experiment) for glomeruli and afferent arterioles, and $n=12$ for renal cortical slices. ${ }^{*} P<0.05$ versus vehicle-treated mice.

cortex expresses endogenous $\beta$-galactosidase that cross reacts with X-gal. Thus, it was difficult to distinguish the L-NAMEinduced from the endogenously produced $\beta$-galactosidase (data not shown).

Interestingly, inhibition of NO by L-NAME increased luciferase activity in the renal vasculature earlier than the onset of blood pressure. Thus, isolated glomeruli displayed an almost twofold increase of luciferase activity after 4 wk of treatment (36 \pm 2 versus $20 \pm 2 \mathrm{LU} / \mu \mathrm{g}, P<0.05$, for $4 \mathrm{wk}$ and control, respectively; Fig. 7, top). The L-NAME-induced activation of procol $\alpha 2$ (I) gene was further increased with time and reached an eightfold increase compared with controls after 14 wk of treatment (152 $\pm 13 \mathrm{LU} / \mu \mathrm{g}$; Fig. 7, top $)$. A similar pattern was observed in afferent arterioles. Luciferase activity started to increase after 4 wk of L-NAME treatment and reached a threefold increase at $14 \mathrm{wk}(184 \pm 4$ versus $252 \pm 10$ and $591 \pm 54$ $\mathrm{LU} / \mu \mathrm{g}, P<0.05$, for control, $4 \mathrm{wk}$ and $14 \mathrm{wk}$ L-NAME treatment; Fig. 7, middle). Procol $\alpha 2(\mathrm{I})$ gene activation was detected after 6 wk of treatment in renal cortical slices and continued to increase up to $14 \mathrm{wk}(157 \pm 6$ versus $206 \pm 8$ and $438 \pm 16 \mathrm{LU} / \mu \mathrm{g}$, $P<0.01$, for control, $6 \mathrm{wk}$ and 14 wk L-NAME treatment; Fig. 7, bottom).

To investigate whether this early activation of collagen I gene was specific to the renal vasculature, luciferase activity was measured in the abdominal aorta and the heart of L-NAMEtreated mice. Contrary to glomeruli, renal microvessels, and cortex, activation of procol $\alpha 2$ (I) gene in aorta was observed much later. $10 \mathrm{wk}$ of $\mathrm{NO}$ inhibition were required at least to detect an increase in the expression of procol $\alpha 2(\mathrm{I})$ gene in aorta $(1,547 \pm 107$ versus $3,100 \pm 145 \mathrm{LU} / \mu \mathrm{g}, P<0.01$, for control and $10 \mathrm{wk}$-treated mice, respectively; Fig. 8, top). The ki-
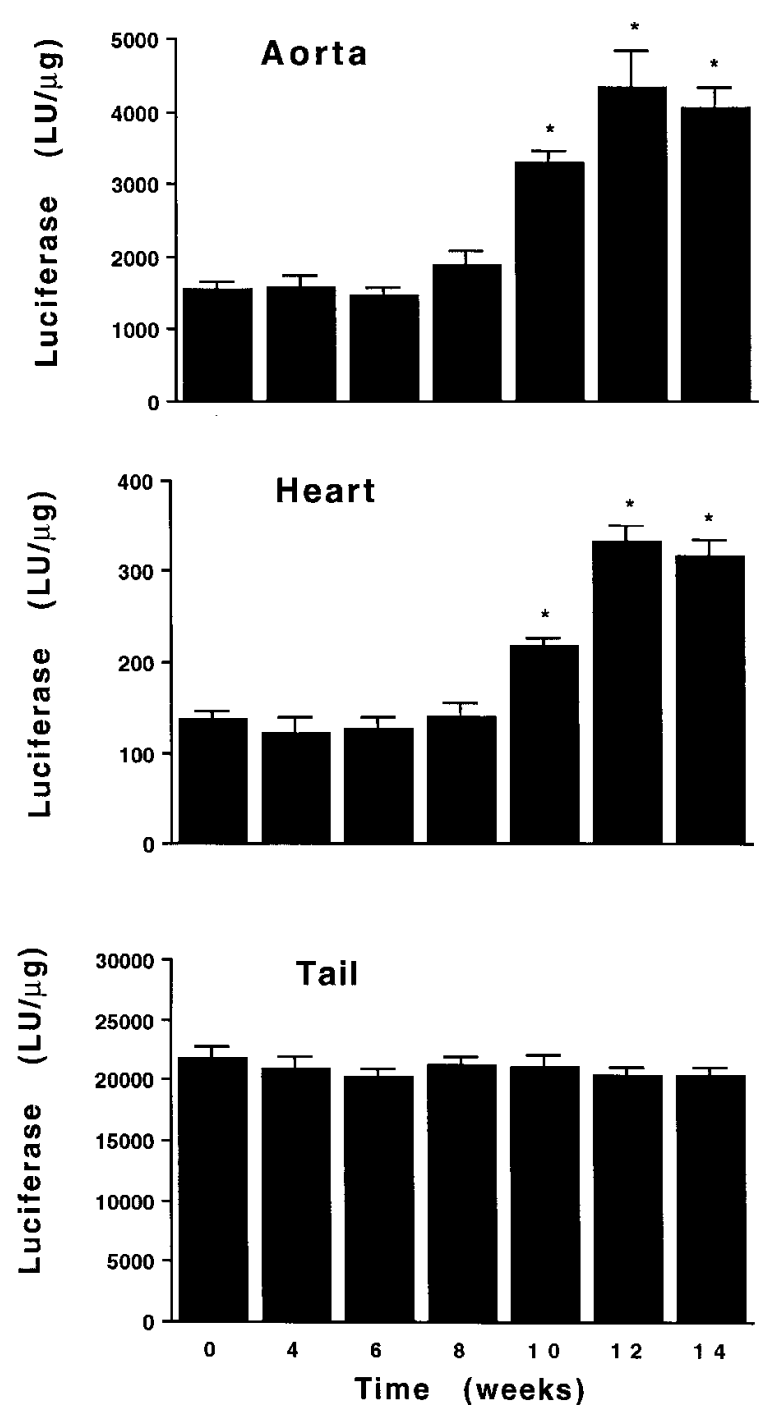

Figure 8. Luciferase activity from aorta (top), heart (middle), and tail (bottom) of L-NAME-treated transgenic mice. Values are means \pm SEM of 12 experiments. $* P<0.05$ versus vehicle-treated mice. 

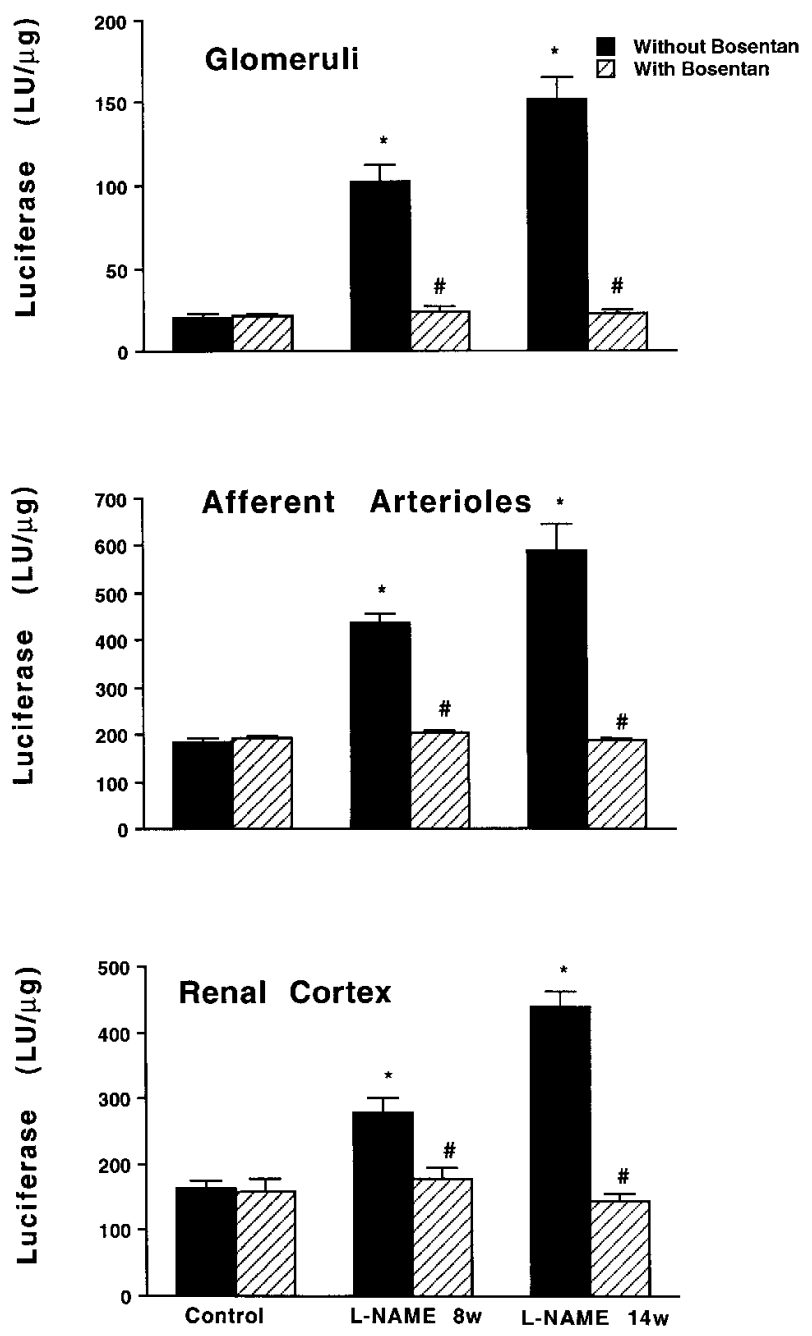

Figure 9. Luciferase activity from glomeruli (top), afferent arterioles (middle), and renal cortical slices (bottom) isolated from controls and mice treated with obsentan, L-NAME, and L-NAME + bosentan. Values are means \pm SEM; $n=3$ (four mice per experiment) for glomeruli and afferent arterioles, and $n=12$ for renal cortical slices. $* P<0.05$ versus control; $\# P<0.05$ L-NAME versus L-NAME + bosentan-treated group.

netic pattern of collagen I gene activation in heart was similar to that of aorta. Luciferase activity in heart became higher after 10 wk of L-NAME treatment $(137 \pm 10$ versus $218 \pm 10 \mathrm{LU} /$ $\mu \mathrm{g}, P<0.01$, for control and $10 \mathrm{wk}$-treated mice, respectively; Fig. 8, middle). Procol $\alpha 2(\mathrm{I})$ gene expression remained unchanged in the tail (Fig. 8, bottom) and the skin (data not shown) of L-NAME-treated animals throughout the experimental period, indicating that nonvascular tissues were not affected by the inhibition of NO synthase.

Effects of bosentan on the L-NAME-treated mice. To gain insight into the mechanism(s) responsible for the activation of procol $\alpha 2$ (I) gene occurring during the inhibition of NO synthesis, we investigated whether endothelin, a potent fibrogenetic agent in vascular smooth muscle cells and mesangial cells (7-9), could be involved in the stimulatory effect of L-NAME. This hypothesis was based on the observation that in mice treated with L-NAME for $10 \mathrm{wk}$, the rate of urinary excre- tion of endothelin was significantly elevated $(4.8 \pm 1.5$ versus $1.9 \pm 0.6 \mathrm{pg} / \mu \mathrm{mol}$ creatinine, $P<0.01$, for L-NAME-treated versus control mice, respectively). To further investigate a possible involvement of endothelin in the fibrogenic process, bosentan, an antagonist of endothelin receptors $\left(\mathrm{ET}_{\mathrm{A}}\right.$ and $\mathrm{ET}_{\mathrm{B}}$ ), was administered in vivo concomitant to L-NAME treatment.

In vivo administration of bosentan had no effect on systolic blood pressure $(119 \pm 3$ versus $117 \pm 2$ and $116 \pm 3 \mathrm{mmHg}$, in controls and mice treated with bosentan for 8 and $14 \mathrm{wk}$, respectively). Similarly, bosentan did not change the systolic pressure of L-NAME-treated rats either at $8 \mathrm{wk}(144 \pm 4$ versus $140 \pm 4 \mathrm{mmHg})$, or at $14 \mathrm{wk}(161 \pm 5$ versus $155 \pm 5 \mathrm{mmHg}$ ), in agreement with the literature for this dose and period of treatment $(12,24)$.

Bosentan administration to control animals did not affect the luciferase activity in any of the tested tissues (Figs. 9 and 10). In contrast, antagonism of endothelin completely blocked the L-NAME-induced activation of procol $\alpha 2(\mathrm{I})$ gene in glomeruli at 8 and $14 \mathrm{wk}(102 \pm 11$ versus $20 \pm 2 \mathrm{LU} / \mu \mathrm{g}$ at $8 \mathrm{wk}, P<$ 0.001 , and $152 \pm 13$ versus $23 \pm 2 \mathrm{LU} / \mu \mathrm{g}$ at $14 \mathrm{wk}, P<0.001$, for L-NAME - and L-NAME + bosentan-treated animals, respectively; Fig. 9, top). Similarly, bosentan completely canceled the increase in luciferase activity induced by L-NAME in afferent arterioles and renal cortex up to $14 \mathrm{wk}$ (Fig. 9, middle
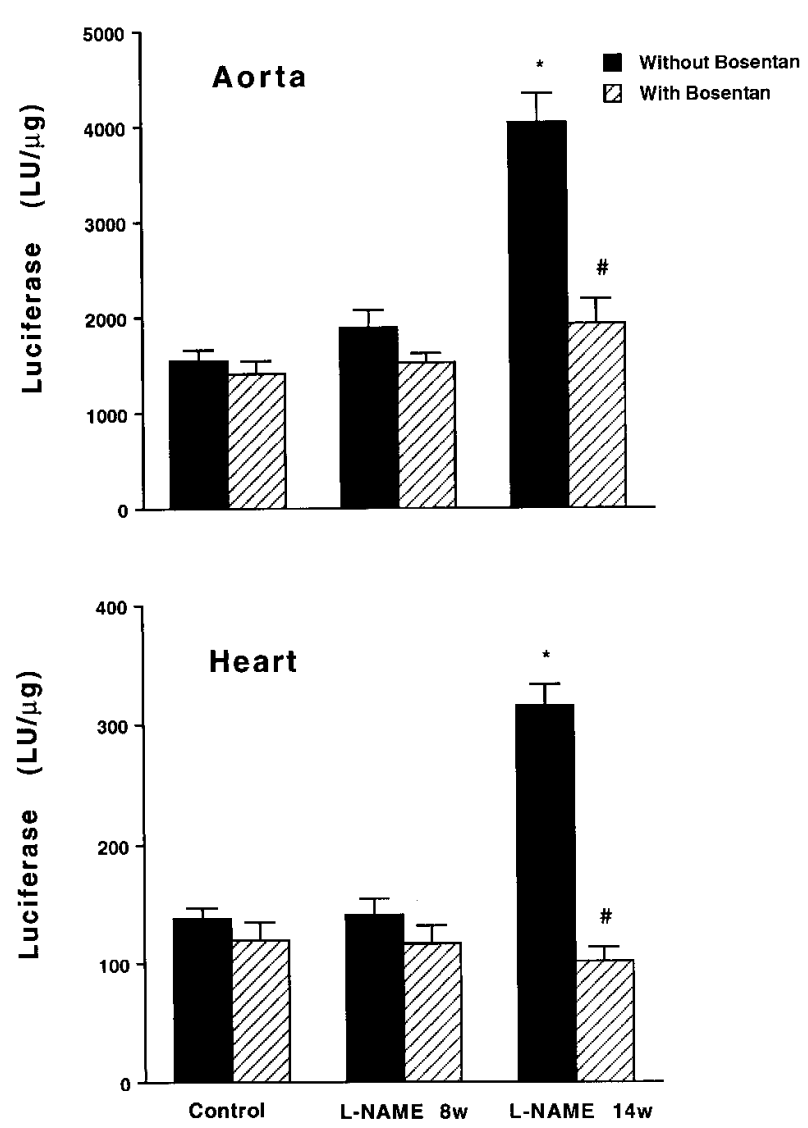

Figure 10. Luciferase activity from aorta (top) and heart (bottom) isolated from controls and mice treated with bosentan, L-NAME, and L-NAME + bosentan. Values are means \pm SEM of 12 experiments. $* P<0.05$ versus control; $\# P<0.05$ L-NAME versus L-NAME + bosentan-treated group. 

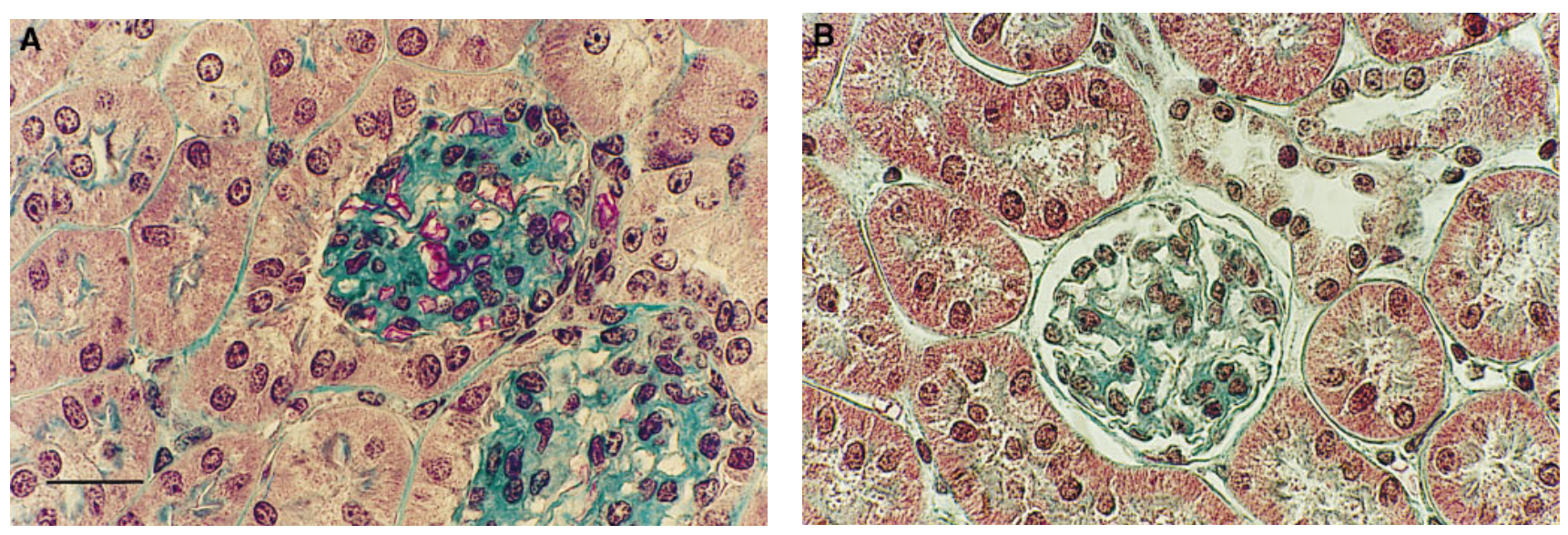

Figure 11. Representative staining of extracellular matrix deposition by Masson trichromic solution in mice treated with L-NAME $(A)$ and L-NAME + bosentan $(B)$ for $14 \mathrm{wk}$, respectively. Note that bosentan blunted the intense green staining characteristic of extracellular matrix in the renal vascular tissue. Bar, $10 \mu \mathrm{m}$.

and bottom) suggesting a specific action of bosentan on collagen I gene activation in renal vasculature independent of the rise of blood pressure.

The inhibitory effect of bosentan on L-NAME-induced activation of procol $\alpha 2(\mathrm{I})$ gene was also observed in the nonrenal vascular tissues. Aorta and heart displayed normal levels of luciferase activity when bosentan was co-administered with L-NAME at 14 wk (aorta: 4,033 \pm 300 versus 1,918 $\pm 274 \mathrm{LU} /$ $\mu \mathrm{g}, P<0.001$; heart: $316 \pm 18$ versus $98 \pm 10 \mathrm{LU} / \mu \mathrm{g}, P<0.001$, for L-NAME - and L-NAME + bosentan-treated animals, respectively; Fig. 10).

To verify whether endothelin can acutely induce collagen type I gene activation in renal tissue of this transgenic strain in vivo, intraperitoneal injections of endothelin were performed in a separate group of animals. Exogenous endothelin slightly increased luciferase activity in renal cortical slices $4 \mathrm{~h}$ after the injections. Luciferase activity was further increased $20 \mathrm{~h}$ after endothelin administration $(155 \pm 8$ versus $211 \pm 17$ and $456 \pm 39$ $\mathrm{LU} / \mu \mathrm{g}, P<0.01$, for 0,4 , and $20 \mathrm{~h}$, respectively).

Bosentan administration protected kidneys from the L-NAME-induced fibrosis as evidenced by the reduced levels of extracellular matrix staining in the representative examples of the L-NAME + bosentan and the L-NAME group shown in Fig. 11. Semiquantitative analysis of fibrosis indicated that only $7.0 \pm 1.3 \%$ of glomeruli exhibited a mild degree of glomerular injury $(2+)$ in the L-NAME+ bosentan group (Fig. 5).

\section{Discussion}

This study provides new information about the mechanism(s) involved in the glomerulo- and nephroangio-sclerotic processes observed during hypertension. Specifically, our results highlight the importance of endogenous NO production and of the balance between NO and endothelin as mediators in the stimulation of extracellular matrix synthesis, particularly collagen type I. Activation of collagen I gene was measured in isolated afferent arterioles and glomeruli during pharmacological blockade of NO synthesis. Essential to our approach was the use of transgenic mice expressing luciferase, a reporter gene, under the control of the promoter of the $\alpha 2$ chain of collagen I gene. The sensitivity and reproducibility of luciferase activity measurements provided us with accurate estimates of tissular (renal vasculature versus heart and aorta) and temporal (before, during, and after the establishment of hypertension) activation of procol $\alpha 2(\mathrm{I})$ gene. A novel finding is that NO inhibition promoted procol 2 (I) expression in the renal vasculature earlier than the blood pressure increase. In addition, we advance some clues for understanding the underlying mechanism(s) since the L-NAME-induced activation of collagen I gene was canceled in the presence of an endothelin receptor antagonist. Thus, the new information provided by our study is: (a) NO synthesis participates in the regulation of collagen I gene activation in the vascular tissue in vivo; $(b)$ an early stimulation of collagen I gene expression occurs in the renal vasculature during NO inhibition and is independent of the systemic hemodynamics; and $(c)$ at least a part of the increased collagen I gene expression is mediated by endothelin.

Expression of collagen type $\mathrm{I}$ is negligible in renal resistance vessels and glomeruli under normal conditions. In sharp contrast, collagen I is highly expressed during the physiopathological process of renal fibrosis, especially nephroangio- and glomerulo-sclerosis $(2,23)$. For this reason, expression of collagen $\mathrm{I}$ is an excellent diagnostic index of renal vascular fibrosis. The line of procol $\alpha 2(\mathrm{I})$ transgenic mouse offers several specific advantages. It is possible to study mechanisms initiating fibrogenesis since collagen gene activation precedes protein formation. Luciferase and $\beta$-galactosidase activity were colocalized in different tissues with collagen I during embryonic development, and in new born and adult animals (reference 16; Fig. 1, right panel; Fig. 2, top), supporting the notion that these two reporter genes provide accurate estimates of collagen I gene expression in vivo. Measurement of luciferase activity is a very sensitive method. For instance, increased procol $\alpha 2$ (I) activation was detected at $4 \mathrm{wk}$ (Fig. 7) whereas increased extracellular matrix formation and high expression of collagen I were detected by conventional morphology and immunohistochemistry at 10 wk (Figs. 4 and 6). A few micrograms of tissue are enough for accurate measurements, the range of linearity is large $(r=0.98$ in the correlation between $\beta$-galactosidase versus luciferase; Fig. 2, bottom), and control tissue values were highly reproducible (SE $<10 \%$ of mean within a tissue). In this transgenic line, the use of our technique 
of isolation of renal resistance vessels and glomeruli $(17,18)$ allowed the study of early mechanisms leading specifically to renal vascular fibrosis. To our knowledge, this is the first study that uses reporter gene expression to investigate mechanisms related to development of hypertension and vascular fibrosis.

Chronic administration of the NO synthase inhibitor L-NAME provides a relatively new experimental model of hypertension $(13,14,25,26)$. The development of hypertension in this model depends on the length and the dose of L-NAME treatment, and is probably due to endothelial dysfunction (25, 26). Renal function is particularly affected during chronic NO inhibition, since L-NAME administration is accompanied by increased afferent and efferent arteriolar and glomerular capillary pressure, and decreased renal blood flow and glomerular filtration rate $(13,26)$. Prolonged administration of L-NAME in rats induces structural damage of the renal vasculature, such as aneurysm, vascular wall thickening, macrophage invasion and glomerular and interstitial fibrosis (12). In our case, histological lesions were not detectable in mouse kidneys during the initial phase of hypertension ( $8 \mathrm{wk}$ ). They became evident after the week 10 , but they remained moderate compared with what has been observed in the rat, probably because of the dose (20 versus $50 \mathrm{mg} / \mathrm{kg}$ ) and/or species difference. Interestingly, procol $1 \alpha 2$ gene activation was detected in afferent arterioles and glomeruli much earlier than in heart and aorta (4 versus 10 wk; Figs. 7 and 8). Our finding is in agreement with previous observations indicating that the appearance of renal lesions and structural damage preceded cardiac and aortic fibrosis (27). These data indicate the importance of the NO pathway in the control of renal vascular remodeling.

The most intriguing observation of our studies is that $\mathrm{NO}$ inhibition stimulated collagen I gene expression in the renal microcirculation before the increase in blood pressure (4 versus 6 wk; Figs. 3 and 7). Several in vitro studies support the hypothesis that NO can regulate extracellular matrix protein synthesis independently of its vasodilatory action. Stimulation of iNOS by IFN $\gamma$ or by lipopolysaccharide reduced, while blockade of iNOS by L-NAME-activated collagen and fibronectin synthesis in cultured mesangial cells (28). NO donors displayed cGMP-mediated antimitotic actions in cultured smooth muscle and mesangial cells $(6,29)$. The L-NAME-induced fibrogenetic effect could be mediated by TGF- $\beta$, since L-NAME increased in parallel TGF- $\beta$ and collagen synthesis in cocultured endothelial-mesangial cells (30). Other studies suggest that during blockade of NO synthase (by L-NAME), the arginase pathway could be activated, thus leading to increased L-proline synthesis, an essential synthesis substrate to collagen formation (31).

Another important observation was that bosentan, an endothelin receptor antagonist, completely canceled the L-NAMEinduced activation of collagen I gene in the renal vasculature during (8-wk) and after (14 wk) the establishment of hypertension. A similar effect was observed in the nonrenal tissues (heart and aorta) at $14 \mathrm{wk}$ indicating that the suppressor effect of endothelin antagonist on collagen I gene activation is general and applies to vascular tissue other than renal. The protective action of bosentan did not depend on its effect on systemic hemodynamics, since bosentan did not change blood pressure in controls or L-NAME-treated mice. The absence of a systemic effect during endothelin antagonism is in agreement with previous studies, where bosentan administration did not alter arterial pressure in spontaneously hypertensive and
L-NAME-treated rats, or in rats with renal mass reduction (12, 24, 32, 33).

The protective effect of bosentan implies that endothelin is involved in the development of vascular fibrosis. In agreement with this notion, endothelin-1 induced cellular proliferation and increased protein, particularly collagen I, synthesis in cultured coronary smooth muscle cells (34). In our model, acute administration of endothelin activated collagen I gene in kidneys of the transgenic mice. It is possible that NO inhibition stimulated the endothelin system (by increasing the transcriptional rate of the endothelin gene, or by activating the intracellular signaling pathway of the endothelin peptide). The fact that the rate of urinary excretion of endothelin was 2.5-fold higher in the L-NAME-treated mice supports the first mechanism. Elevation of NO production reduced, whereas inhibition of NO synthesis increased, expression of endothelin-1 transcription levels in human endothelial cells (35) further supporting this hypothesis. Similarly, the production of endothelin from aortic vessels was inhibited in presence of NO and potentiated during NO inhibition (36). In addition, antagonism of endothelin receptors blunted the systemic and renal vasoconstrictor effect produced during NO inhibition in anesthetized rats (37). It is also possible that the action of endothelin system became stronger in the absence of the counterbalancing action of NO.

Several recent studies imply that endothelin plays a major role on the mechanisms of nephroangio- and glomerulo-sclerosis. Thus, antagonism of endothelin receptors delayed the evolution of renal failure (as evidenced by measurements of creatinine and urine protein, and by histological analysis) and increased the survival rate in rats with renal mass reduction $(38,39)$. Similarly, in the model of murine lupus nephritis, use of an endothelin receptor antagonist improved renal structural damage and reduced extracellular matrix, including collagen I, III, and IV, laminin and proteoglycan, formation (40). More recently, it was observed that transgenic mice overexpressing human endothelin 1 gene developed glomerulosclerosis and interstitial fibrosis (41). It is noteworthy that the appearance of these renal lesions was not accompanied by changes in arterial pressure thus, corroborating the hypothesis that the endothelin-mediated fibrogenic mechanisms are independent of systemic hemodynamics.

In conclusion, the model of transgenic mouse harboring the luciferase reporter gene under the control of collagen I promoter, permitted to investigate early mechanisms in the development of renal fibrosis. NO plays a major role in the mechanisms controlling collagen I gene expression in the renal vasculature, because prolonged inhibition of NO synthesis induced a local renal activation of collagen I gene. This fibrogenic effect is probably independent of systemic hemodynamics and is, at least partly, mediated by the action of endothelin presumably triggered by inhibition of NO synthesis. These data indicate the importance of the balance between endothelial vasodilators/vasoconstrictors in the physiopathological mechanisms controlling extracellular matrix synthesis during fibrogenesis.

\section{Acknowledgments}

The authors thank Dr. George Bou-Gharios, Dr. Jerôme Rossert, and Dr. Benoit de Crombrugghe (Department of Molecular Genetics, University of Texas, Houston) for providing the transgenic mice, 
Pr. Patrice Callard for facilitating the collection of histology data, and Dr. Martine Clozel (Hoffman-LaRoche, Switzerland) for providing bosentan. The authors express their gratitude to Dr. Katia Kordeli, Marie-Aline Ludosky, and Odile Cohin for the substantial help in the immunohistochemistry studies.

This work was supported by the Institut National de la Santé et de la Recherche Médicale and the Faculté de Médicine St. Antoine. Dr. J.J. Boffa was a research fellow of the Fondation pour la Recherche Médicale.

\section{References}

1. Weistucch, J.M., and L.D. Dworkin. 1992. Does essential hypertension cause end-stage renal disease? Kidney Int. 41:S33-S37.

2. Yoshioka, K., M. Tohda, T. Takemura, N. Akano, K. Matsubara, A. Ooshima, and S. Maki. 1990. Distribution of the type I collagen in human kidney diseases in comparison with type III collagen. J. Pathol. 162:141-148.

3. Palmer, R.M., D.S. Ashton, and S. Moncada 1988. Vascular endothelial cells synthesize nitric oxide from L-arginine. Nature. 333:664-666.

4. Yanisigawa, M., H. Kurihara, S. Kimura, Y. Tomobe, M. Kobayashi, Y. Mitsui, Y. Yazaki, K. Goto, and T. Masaki. 1988. A novel potent vasoconstrictor peptide produced by vascular endothelial cells. Nature. 332:411-415.

5. Hayakawa, H., and L. Raij. 1997. The link among nitric oxide synthase activity, endothelial function, and aortic and ventricular hypertrophy in hypertension. Hypertension (Dallas). 29:235-241.

6. Garg, U.C., and A. Hassid. 1989. Nitric-oxide generating vasodilators and 8-bromo-cyclic guanosine monophosphate inhibit mitogenesis and proliferation of cultured rat vascular smooth muscle cells. J. Clin. Invest. 83:1774-1777.

7. Hirata, Y., Y. Takagi, Y. Fukuda, and F. Marumo. 1989. Endothelin is a potent mitogen for rat vascular smooth muscle cells. Atherosclerosis. 78:225-228.

8. Chua, B.H.L., C.J. Krebs, C.C. Chua, and C.A. Diglio. 1992. Endothelin stimulates protein synthesis in smooth muscle cells. Am. J. Physiol. 262(Endocrine Physiol. 31):E412-E416.

9. Simonson, M.S., S. Wann, P. Mene, G.R. Dubyak, M. Kester, Y. Nakazato, J.R. Sedor, and M.J. Dunn. 1989. Endothelin stimulates phospholipase C, $\mathrm{Na}^{+} / \mathrm{H}^{+}$exchange, c-fos expression, and mitogenesis in rat mesangial cells. $J$. Clin. Invest. 83:708-712.

10. Li, J.S., R. Larivière, and E.L. Schiffrin. 1994. Effect of a nonselective endothelin antagonist on vascular remodeling in deoxycorticosterone acetatesalt hypertensive rats: evidence for a role of endothelin in vascular hypertrophy? Hypertension (Dallas). 24:183-188.

11. Moreau, P., L.V. d'Uscio, S. Shaw, H. Takase, M. Barton, and T.F. Lüscher. 1997. Angiotensin II increases tissue endothelin and induces vascular hypertrophy: reversal by $\mathrm{ET}_{\mathrm{A}}$-receptor antagonist. Circulation. 96:1593-1597.

12. Bouriquet, N., M. Dupont, A. Herizi, A. Mimran, and D. Casellas. 1996. Preglomerular sudanophilia in L-NAME hypertensive rats: involvement of endothelin. Hypertension (Dallas). 27:382-391.

13. Baylis, C., B. Mitruka, and A. Deng. 1992. Chronic blockade of nitric oxide synthesis in the rat produces systemic hypertension and glomerular damage. J. Clin. Invest. 90:278-281.

14. Ribeiro, M.O., E. Antunes, G. De Nucci, S.M. Lovisolo, and R. Zatz. 1992. Chronic inhibition of nitric oxide synthesis. A new model of arterial hypertension. Hypertension (Dallas). 20:298-303.

15. Arnal, J.F., L. Warin, and J.B. Michel. 1992. Determinants of aortic cyclic guanosine monophosphate in hypertension induced by chronic inhibition of nitric oxide synthase. J. Clin. Invest. 90:647-652.

16. Bou-Gharios, G., L.A. Garrett, J. Rossert, K. Niederreither, H. Eberspaecher, C. Smith, C. Black, and B. de Crombrugghe. 1996. A potent farupstream enhancer in the mouse prox2(I) collagen gene results expression of reporter genes in transgenic mice. J. Cell Biol. 134:1333-1344.

17. Chatziantoniou, C., and W.J. Arendshorst. 1993. Angiotensin receptor sites in renal vasculature of rats developing genetic hypertension. Am. J. Physiol. 265(Renal Fluid Electrolyte Physiol. 34):F853-F862.

18. Chatziantoniou, C., M.D. Pauti, F. Pinet, D. Promeneur, J.C. Dussaule, and R. Ardaillou. 1996. Renin release is impaired after nitric oxide inhibition. Kidney Int. 49:626-633.
19. Clozel, M., V. Breu, G.A. Gray, B. Kalina, B.M. Löffler, K. Burri, J.M. Cassal, G. Hirth, M. Müller, W. Neidhart, and H. Ramuz. 1994. Pharmacological characterization of bosentan, a new potent orally active nonpeptide endothelin receptor antagonist. J. Pharmacol. Exp. Ther. 270:228-235.

20. Bradford, M.M. 1976. A rapid and sensitive method for the quantitation of microgram quantities of protein utilizing the principle of protein dye binding. Anal. Biochem. 72:248-251.

21. Benigni, A., N. Perico, F. Gaspari, C. Zoja, L. Belizzi, M. Cabanelli, and G. Remuzzi. 1991. Increased renal endothelin in rats with reduced renal mass. Am. J. Physiol. 260(Renal Fluid Electrolyte Physiol. 29):F331-F339.

22. Rossert, J., and B. de Crombrugghe. 1996. Type I collagen: structure, synthesis, and regulation. In Principles of Bone Biology, Academic Press, San Diego, CA. 127-142.

23. Striker, L., P.D. Killen, E. Chi, and G.E. Striker. 1984. The composition of glomerulosclerosis. Studies in focal sclerosis, crescentic glomerulonephritis, and membranoproliferative glomerulonephritis. Lab. Invest. 51:181-192.

24. Li, J.S., and E.L. Schiffrin. 1995. Effect of chronic treatment of adult spontaneously hypertensive rats with an endothelin receptor antagonist. Hypertension (Dallas). 25:495-500.

25. Arnal, J.F., J.B. Michel, and D.G. Harrison. 1995. Nitric oxide in the pathogenesis of hypertension. Curr. Opin. Nephrol. Hypertens. 4:182-188.

26. Raij, L., and C. Baylis. 1995. Editorial review: glomerular actions of nitric oxide. Kidney Int. 48:20-32.

27. Xu, Y., J.F. Arnal, N. Hinglais, M.D. Appay, I. Laboulandine, J. Bariety, and J.B. Michel. 1995. Renal hypertensive angiopathy. Comparison between chronic NO suppression and DOCA-salt intoxication. Am. J. Hypertens. 8:167-176.

28. Trachtman, H., S. Futterweit, and P.C. Singhal. 1995. Nitric oxide modulates the synthesis of extracellular matrix proteins in cultured rat mesangial cells. Biochem. Biophys. Res. Commun. 207:120-125.

29. Garg, U.C., and A. Hassid. 1989. Inhibition of rat mesangial cell mitogenesis by nitric oxide-generating vasodilators. Am. J. Physiol. 257(Renal Fluid Electrolyte Physiol. 26):F60-F66.

30. Craven, P., R.K. Studer, J. Felder, S. Phillips, and F.R. Derubertis. 1997. Nitric oxide inhibition of transforming growth factor $-\beta$ and collagen synthesis in mesangial cells. Diabetes. 46:671-681.

31. Ketteler, M., W. Border, and N. Noble. 1994. Cytokines and L-arginine in renal injury and repair. Am. J. Physiol. 267:F197-F207.

32. Moreau, P., H. Takase, C.F. Küng, S. Shaw, and T.F. Lüscher. 1997. Blood pressure and vascular effects of endothelin blockage in chronic nitric oxide deficient hypertension. Hypertension. 29:763-769.

33. Pollock, D., and J. Polakowski. 1997. ET-A receptor blockade prevents hypertension associated with exogenous endothelin-1 but not renal mass reduction in the rat. J. Am. Soc. Nephrol. 8:1054-1060.

34. Rivzi, M., and P.R. Myers. 1997. Nitric oxide modulates basal and endothelin induced coronary artery vascular smooth muscle cell proliferation and collagen levels. J. Mol. Cell Cardiol. 29:1779-1789.

35. Phelan, M., S. Perrine, M. Brauer, and D.G. Faller. 1995. Sickle erythrocytes, after sickling, regulate the endothelin-1 gene and protein in human endothelial cells in culture. J. Clin. Invest. 96:1445-1451.

36. Boulanger, C., and T. Lüscher. 1990. Release of endothelin from the porcine aorta. J. Clin. Invest. 85:587-590.

37. Thompson, A.C., R. Valeri, and W. Lieberthal. 1995. Endothelin receptor A blockade alters hemodynamic response to nitric oxide inhibition in rats. Am. J. Physiol. 269(Heart Circulatory Physiol. 38):H743-H748.

38. Benigni, A., C. Zoja, D. Corna, S. Orisio, L. Longaretti, T. Bertani, and G. Remuzzi. 1993. A specific endothelin subtype A receptor antagonist protects against injury in renal disease progression. Kidney Int. 44:440-444.

39. Benigni, A., C. Zoja, D. Corna, S. Orisio, D. Facchinetti, T. Bertani, and G. Remuzzi. 1996. Blocking both type A and B endothelin receptors in the kidney attenuates renal injury and prolongs survival in rats with remnant kidney. Am. J. Kidney Dis. 27:416-423.

40. Nakamura, T., I. Ebihara, H. Tomino, and H. Koide. 1995. Effect of a specific endothelin A receptor antagonist on murine lupus nephritis. Kidney Int. 47:481-489.

41. Hocher, B., C. Thöne-Reineke, P. Rohmeiss, F. Schmager, T. Slowinski, V. Burst, F. Siegmund, T. Quertermous, H.H. Neumayer, W.D. Schleuning, and F. Theuring. 1997. Endothelin-1 transgenic mice develops glomerulosclerosis, interstitial fibrosis, and renal cysts but not hypertension. J. Clin. Invest. 99: 1380-1389. 